\title{
Bats, Rabies and Control Problems
}

\section{By Arthur M. Greenhall}

In both North and South America rabies is carried by bats, especially the vampire bats in the warmer central countries. Every country in the two continents, with only three exceptions, and every state in the USA, with only two exceptions, has reported rabid bats. As rabies is fatal to both humans and domestic animals control measures are essential. The author, who was for many $y$ zars in charge of vampire-bat control in Trinidad, where in the ten years up to 1935, 89 humans and thousands of cattle died of paralytic rabies, emphasises that bats are beneficial animals and that control must be aimed, not at indiscriminate destruction of bats, but to regulate the population levels, and that care must be taken not to involve other species.

$\mathbf{U}$

NDER normal circumstances, bats are beneficial mammals whose activities are useful to man, but occasionally the population density of a species rises to a level where agricultural damage of economic significance occurs or public health is threatened. At this point the species is usually regarded as a pest. Controls may be initiated against the offender and if improperly conducted may cause just criticism. Frequently there is a failure to identify correctly the species involved or properly define the problem. The ecological approach should be stressed since the aim of control is: (1) the regulation of population levels of the offending species, and not merely the indiscriminate destruction of individuals, and (2) the protection of non-target species in every way possible.

Insectivorous bats of both temperate and tropical regions consume nightly enormous quantities of insects which, without some agency to control their numbers, would become overabundant. In the tropics, some bats serve as useful predators, feeding upon fish, lizards, birds and mammals. Others, such as the long-tongued glossophagine bats that feed upon nectar, are essential pollinators for certain trees, while most of the fruiteating phyllostomine bats propagate a number of economically important trees by the dissemination of seeds.

Not infrequently major habitat alterations by man occur which favour the reproductive potential of a particular species. For example, with the development of Post-Columbian Latin America, new settlements, with their buildings, introduced crops and livestock have attracted certain bats to new roosting places and induced a change in their habits. Many species abandoned cave or tree roosts to live in man-made structures. Some fruit-eating bats now feed on cultivated fruits, preferring them to the indigenous kinds; while the blood-drinking vampire bats have found man and domestic animals a more accessible and plentiful food source than was provided by wild animals and birds. These adaptable species

Dr Greenhall is a Bureau of Sport Fisheries and Wildlife Research Associate working at the Smithsonian Institution, Washington, D.C. 
benefited and their numbers increased, in some instances to alarming proportions. The close contact between these bats, humans and animals facilitates the easy transmission of various pathogens. One such disease, fatal to man and animals, is rabies, which may be associated with overpopulation (Johnson, 1959; Tierkel, 1963). Since all New World bats are potentially vectors of rabies, it appears that the adaptable species which increased their numbers are those that create the public health and agricultural problems requiring control.

In 1953 widespread attention was focused on the public health importance of bats when rabies was isolated from insectivorous bats in the United States. Previously, bat rabies had been reported only from Latin America and Trinidad. As of December 1967, every state in the United States, except Alaska and Hawaii, had reported rabid bats, as had also every country in North and South America with the exception of Peru, Chile and Uruguay. A few cases of bat rabies have also been reported from Europe and Asia; but as yet none from Africa or Australia. Bat rabies has not yet become a problem in the Eastern Hemisphere.

Although rabies has been reported from about 50 species of bats from Canada to Argentina, including Trinidad, it is the sanguivorous vampire bats that are the most important vectors. These bats are restricted to the warmer portions of Mexico, Central and South America. It is not known whether rabies in bats existed before the discovery of the New World. Today, however, "vampire bat rabies is the major cause of death in cattle in Latin America and has proved a major obstacle to the expansion of its agricultural economy' (5th WHO Rabies Rept. 1966). Mass vaccination of cattle has been used as the principal weapon in rabies control. Attempts also have been made to control vampire bats by gassing, shooting poisoning and trapping. The success of such measures in reducing vampire bat populations largely depends upon their intelligent application. Unfortunately some bat control programmes in Latin America are nonselective, resulting in the destruction of many bat species other than vampires.

Howard (1965) in discussing philosophical conclusions about the control of vertebrates, states that: ' $\ldots$ the primary objective of all control methods should be to accomplish the desired effect with a maximum safety to man and to forms of life useful or of neutral values to him, and that they be carried out with a minimum of disturbance to the biotic community.'

I attempted to achieve this objective in Trinidad, where for many years I was in charge of a vampire-bat control programme. As a result of outbreaks of paralytic rabies between 1925 and 1935, thousands of cattle and 89 humans died in Trinidad. In $1934 \mathrm{I}$ assisted in organising the control programme but did not direct it until 1954. However, it has continued uninterrupted since its inception. The annual average of 2,000 vampire bats collected for virus study and to reduce the population represented a saving each year of about 3,720 gallons of blood which otherwise would have been drained from Trinidad livestock.

Three groups of vampire bats are known, Desmodus, Diaemus and 
Diphylla, each rabies positive throughout Latin America. Desmodus is the most important vector of bat rabies as it is one of the most abundant of all tropical bats. In Trinidad, Desmodus was found roosting in association with 17 other species of bats. Some of these are of economic importance in that they consume insects, are pollinators, seed disseminators or useful predators. (Goodwin and Greenhall, 1961). Except when specific reasons arose for collecting other bats, control in Trinidad was directed exclusively toward the vampire bats, Desmodus and the less abundant Diaemus

Early in 1966, the United Nations sent a joint FAO/WHO Mission to appraise and define the bat rabies problem in parts of South America, Trinidad and Mexico. The Mission noted with alarm the increase of bat rabies as a phenomenon corresponding to a similar increase of rabies generally throughout the world. It further noted that rabies gravely limited the development of livestock in regions where vampires exist, and that the affected areas may extend with the expansion of cattle raising. It was requested that FAO assist the Mexican Government in establishing a project to be based at the Agricultural Research Centre at Palo Alto, near Mexico City to investigate all aspects of bat rabies including an ecological study of vampire bats with special emphasis on control methods. The Mission also recommended a broad long-term programme for the application of technical advances in different livestock regions of Latin America and to support a second phase project to include participation by research centres in other countries. The ecological approach should be stressed since the aim of control is the regulation of population levels and not merely the indiscriminate destruction of individuals or populations. In all such regulations, due consideration should be given to the protection of nontarget species. The fear that the destruction of vampire bats may upset the balance of nature is unrealistic since the balance already has been upset by the introduction of livestock.' 'Balanced' vampire-bat populations probably exist today only in areas where domestic animals and poultry never have been introduced, e.g., the bird guano islands off western South America and remote virgin rain forests where the bats must feed upon the indigenous fauna. Since the complete eradication of all vampire bats is probably impossible (whether desirable or not) due to their tremendous distribution, abundance and inaccessible roosts, it is more practical to think in terms of selective control, especially of local populations in high risk problem areas.

In the temperate United States and Canada, where all bats are insectivorous, little bat control work has been undertaken. Where rabid bats have been found, the public is generally warned not to pick up or handle sick or strangely behaving bats.

Following the first isolation, in 1953, of bat rabies in the United States, interest in bats intensified and there was a great forward surge in such basic studies as the taxonomy, distribution and life histories of American bats. Annually thousands of bats are banded with numbered metal bands which are affixed to the forearm of various species. The US Fish and Wildlife Service issues bands to qualified scientists to study migrations, 
homing tendencies, sex ratios, breed ng habits, growth rates, longevity and the general ecology of bats. Many large-scale banding operations to determine the extent of rabies infections have been financed by Federal and State public health agencies, especially in southwestern United States.

Since about 1963, bat banders in the United States have reported instances of indiscriminate killing and senseless removal of bats from caves, resulting in a decline in bat populations of some caves. This state of affairs was brought to the attention of the American Society of Mammalogists at its 44th Annual Meeting in Mexico City on 17th June, 1964. A resolution was passed which endorsed the bat-banding programme and resolved that, except for scientific research, the removal, molestation or disturbance of bats and their roosts should be discouraged since some species could be endangered by removing large numbers or by damaging roosts.

\section{REFERENCES}

AMERICAN SOCIETY OF MAMMALOGISTS, 1964. Cave bat population resolution. Jour. Mammalogy. 45 (4): 669-670.

GOODWIN, G. G., AND GREENHALL, A. M., 1961. A review of the bats of Trinidad and Tobago: Descriptions, rabies infection and ecology. Bull. Amer. Mus. Nat. Hist., 122 (3): 187-302.

GREENHALL, A. M., 1964. Bats: their public health importance and control with special reference to Trinidad. Proc. Second Vertebrate Pest Control Conf., Anaheim, Calif. March 1964, pp. 108-116. (Published by U. California, Davis.) HOWARD, W. E., 1965. Principles of vertebrate animal control. Congrès de la Protection des Cultures Tropicales. Marseille, France, March 1965. pp. 627-629. JOHNSON, H. N., 1959. Rabies. Chap. 21, in Viral and Rickettsial Infections of Man. Eds. J. M. Rivers and F. L. Horsfall, Jr., 3rd Ed. J. B. Lippencott Co., Philadelphia.

MANN, F. G., 1954. Las aves guaneras y las posibilidades de incrementar la produccion de guana blanco en Chile. Rev. Chile Hist. Nat. 54 (16): 191-227.

TIERKEL, E. S., 1963. Rabies. Chap. 9. in Diseases transmitted from animals to man. Ed. T. C. Hull, 5th Ed. C. C. Thomas, Springfield, Illinois.

UNITED NATIONS DEVELOPMENT PROGRAMME (Special Fund), 1966. Report of the preparatory assistance mission (FAO/WHO) to Latin America. DP/SF/310/MEX 16, 90 pp. March 14, 1966, mimeographed.

WORLD HEALTH ORGANISATION, 1966. WHO expert committee on rabies. 5th Report. WHO Technical Report Series. No. 321, pp. 1-28.

\section{White and Black Rhinoceros in Rhodesia Corrections and Supplementary Information}

Because of some inaccuracies in the map of Rhodesia on pages 224-225 of the December issue of ORYX, this is being redrawn and readers may obtain a copy on application to the FPS. On page 223 the literature reference should be Roth and Child (1967); page 228, last line, Lake Kyle should be substituted for Lake Kariba; page 229 , line 15 , after 'rhinoceros', insert, 'and this contributed to covering the expenses'.

Of the illustrations, plate 15 showed a black, not white, rhinoceros, and in plate 13 the rhino was standing numb. The white rhino on plate 12 was captured in the Umfolozi Game Reserve for removal to Rhodesia; the one in plate 16 was awaiting release into Kyle Dam Reserve. The prehistoric rock painting on page 219 was of a white rhinoceros in the Matopos National Park, into which this species was reintroduced. 